\title{
HUMAN EQUALITY AND INTRA- AS WELL AS INTERCULTURAL DIVERSITY
}

In examining the question "What is common to all people and how do they differ?" three typological stages may be distinguished: a Platonic thesis, a romantic antithesis, and a current synthesis-the last a hypothesis that is advanced today in human biology and linguistic studies.

\section{The Platonic Thesis}

The locus classicus of the Platonic thesis occurs not in Plato but in the work of his pupil, Aristotle, at the beginning of a small and probably early tract $D e$ interpretatione:

Just as written marks are not the same for all human beings, neither are spoken

sounds. But what these are in the first place signs of-affections of the soul-are the same for all; and what these affections are likenesses of-things-are also the same. ${ }^{1}$

The suggestion is that people are all concerned with the same things. They also have the same mental ideas of these things. The expression of these ideas, however, varies from culture to culture.

The philosophy that underlines this view is obviously Platonic: inside and outside, being and appearance, and, in the case of language, content and expression as well as text and context, are opposites. The first member of each pair is independent of the second one. The first member contains the essential, is considered invariable, and is universally the same; in contrast, the second term is changeable, particular, and is what it is only by accident.

Appropriately enough, it is only the linguistic terminology of this "ideology" that has changed over the centuries. In Plato's dialogue Cratylos, ${ }^{2}$ the ideal content of a word (to tou onomatos eidos), as something universal, was opposed to its syllables (syllabai) as particulars, and in Aristotle's just-quoted treatise "On Interpretation," the mental impressions (pathēmata tès psychēs) were opposed to the speech sounds (phonai). Similarly juxtaposed as invariant and variable in the Middle Ages were the substantial content of discourse (substantia sermonis) and its phonetic articulation (articulatio vocis); ${ }^{3}$ Leibniz, ${ }^{4}$ at the turn of the 18 th century, juxtaposed ideas (les idées) and words (les mots); and Husserl, ${ }^{5}$ at the

\footnotetext{
"Human Equality and Intra- as well as Intercultural Diversity" by Elmar Holenstein, The Monist, vol. 78, no. 1, pp. 65-79. Copyright @ 1995, THE MONIST, La Salle, Illinois 61301.
} 
beginning of this century, juxtaposed the meaning-categories (Bedeutungskategorien) of languages and the categories of their expression (Ausdruck). In this tradition, the view has occasionally been imputed to Chomsky, ${ }^{6}$ the best-known exponent of an alternative view of language universals, that the deep structure of languages is universal as opposed to their particular surface structures. Leibniz advances the same argument regarding ethics, according to which the concept of virtue (la notion de la vertu en général) is the same for all people; only its application varies, although, as he remarks, "less than one would think."

The designation of this thesis as Platonic is Eurocentric, and contradicts its claim to universal validity. It is, in fact, a proverbial dictum common to many cultures.

From the Rig Veda, a collection of hymns dating back to the second millenium B.C., Indian philosophers traditionally quote the proposition, Ekam sad, viprä bahudhā vadanti: "One being, the wise name it differently." Or: "One truth, the wise say it differently." 8

In the 9th and 10th or, according to the Muhammadan calendar, the 3rd and 4th centuries, Al-Farabi, an Islamic philosopher of Turkish descent and born in present-day Kazakhstan, taught that (philosophical) truth is universal and that only its (religious) symbols change from nation to nation: unity of (sage) philosophy and diversity of (folk) religions. ${ }^{9}$

Possibly in the wake of Islamic precedent, Nicholas of Cusa, in his tract On the Peace of Faith, came up with the formula, religio una in rituum varietate: "One religion in a diversity of rites/symbols/ceremonies." 10

This same mode of thinking, thus substantiated with quotes from the Rig $V e d a$, Plato, Aristotle, Islamic philosophers and medieval grammarians, Cusanus, Leibniz, Husserl, and the secondary literature of current linguistics, made a recent appearance (1987) in the title of a lecture by Jürgen Habermas: "The Unity of Reason in the Multiplicity of its Voices."11 We are evidently dealing with a very deeply rooted mode of thinking. But transcultural spread is not evidence of truth.

An alternative view of things, which is of theoretical currency today in many fields of scholarship and the subject of the third thesis in this paper, is reflected in another time-honored, proverbial maxim. Its Chinese origins are telling. It is quoted at this juncture because it occasionally receives the same monistic interpretation as the above-cited examples from world literature. It reads: san jiao - yi jia. ${ }^{12}$ Arthur Schopenhauer transliterates san kiao - $i$ kia and translates "three teachings—one family" and reads the slogan as meaning that "the three teachings are only one." 13 The word jia, rendered by Schopenhauer as 'family', a reading that begs a monistic interpretation, actually also means 'house' or 'household'. The latter translation allows a presumably older, more accurate, and in any case more interesting interpretation: The three teachings complement each other and 
together they make the house complete. According to one source, the three teachings originally meant the three basic values of Confucianism: piety, loyalty, and nobility. Later they were said to refer to the three main philosophical currents in China: Confucianism, Daoism, and Buddhism. The historical heterogeneity of these three world-views, each with different roots in northern China, southern China, and India respectively, suggests a complementaristic reading. By contrast, the historical affinity of the three monotheistic religions of Judaism, Christianity, and Islam, which prevail in the Western world, has encouraged uniformistic thinking since the Middle Ages and the Age of Enlightenment down to the present day.

If all people are confronted with the same things and acquire the same ideas from them, and if only the language with which they lend expression to their thoughts varies, then intercultural understanding is not an impossibility; on the contrary, it is a relatively simple affair. One need only dispense with the verbal shell, the words that sow confusion, and focus on the things themselves, the ideas themselves-as put forward by John Locke in the 17 th century ${ }^{14}$ and reiterated by Edmund Husserl at the beginning of this century. ${ }^{15}$

The most trenchant formulation of this conviction is found in the writings of Bishop Berkeley: "We need only draw the curtain of words, to behold the fairest tree of knowledge, whose fruit is excellent, and within the reach of our hand."16

His statement actually embodies three classical convictions all of which seem doubtful to us today: (a) Knowledge is possible without language. (b) The essence of things, truth, is accessible and not beyond comprehensibility; it does not recede the more we reach out to it. (c) Truth is something delicious that enhances our well-being; it is not a bitter fruit, not something ominous that we had best not engage with.

\section{The Romantic Antithesis}

In the course of the 18th century, the insight gained ground that knowledge and language are not independent of each other. In natural languages the phonological and grammatical structure of utterances affect their meaning. Two illuminating examples may suffice by way of illustration.

The German word Alptraum elicits different associations from the English word nightmare, despite the fact that both words are derived from the idea of a kobold (Elf/Alb; mare) that assails the sleeper. Only with the German word do we associate the weight of the Alps, which threaten to crush the dreamer, an idea that has gradually affected the meaning of the word.

In a formalized language, we can enumerate objects regardless of sequence. In the operation of addition, which is governed by the law of commutability, it makes no difference whether we add $2+3$ or $3+2$. Not so with natural 
languages: Bush and Baker is not equivalent in meaning to Baker and Bush, nor is milk and coffee to coffee and milk. In natural languages, the order of a sequence contains information. As a rule, order reflects rank. The dominant, more important item comes first. If you ask for milk and coffee, then milk is the main beverage and coffee the extra; but the rank is reversed when you ask for coffee and milk.

Meaning is affected not only by the manner in which we say something, but also by the context in which we use our words. Once again two illustrations shall suffice.

On the European continent, a federal state is seen in terms of the powers that are bestowed upon its parts; the Anglo-American view emphasizes the jurisdiction ceded by the parts to the central government. To Europeans, therefore, federalism means decentralization; to Anglo-Americans, it means centralization.

In Germany, the word selbstbewusst designates someone who knows what he knows and oozes self-confidence; the same word in England, self-conscious, designates someone who knows what he does not know and is acutely aware of his limitations.

Languages differ from each other per definitionem in their phonological and grammatical structure, and cultures differ through the context, the historical and social framework, in which they use words. It is thus impossible to translate even one page of a book written in a natural language into one page of a book in another language with the same semantic, associative, and connotative nuances.

The Platonic thesis was based on the assumption that inside and outside, essence and appearance, the essential and the random, and in the case of language, content and expression as well as text and context are mutually independent. For the romantic antithesis organic, holistic thinking is typical. A functional, purposeful, meaningful connection is assumed not only among the parts of a single whole, so that no part can be changed or even exchanged without affecting all the other parts, but also between form and material or form and function (in turn regarded as parts or partial aspects of a whole). Everything is linked and attuned to everything else, so much so that the distinction between essential and nonessential falls away.

If meaning depends on expression and text on context, one cannot lay claim to equivalence between different languages and different cultures. A typical rendition of this romantic view is found in Wilhelm von Humboldt's writings:

Since all objective perception is inevitably tinged with subjectivity, one can vieweven apart from language-all human individuality as a singular standpoint of the worldview. It is even more so through language ...; and since in the same nation a similar subjectivity affects language, there lies in every language an idiosyncratic worldview. . . Man lives with things mainly [!], in fact since sensations and actions depend on his ideas even exclusively [!], the way they are adduced to him by language. 17 
The now commonly accepted linguistic determinism and relativism reflected in this passage raises three issues: (a) The extent of linguistic determinism remains unclear. Within one and the same sentence, the experience of things is declared to be mainly and exclusively dependent upon language. (b) The assumption that objective perception depends on subjective structures takes only two of three possible variants into consideration: Variation in subjective structures is contingent upon (1) individual and (2) national (cultural) factors. The possibility that there may also be (3) species-specific mental structures common to all human beings has not entered the argument. (c) Nor is reflection expended upon whether variation in the subjective structures of human beings is unlimited and arbitrary or whether there are natural constraints to their change (fluctuation), their suitability (convenience) and their practicability (viability). What interests us here is whether we really must toe the line of unrestricted pluralism. For pluralism of this kind, everything is ultimately no less indifferent than for rationalist forms of classical universalism.

Herder impressively described the logical consequences of the romantic cultural model, introduced by him, for intercultural understanding:

Every nation has its center of bliss within itself as every sphere has its center of gravity!-everything that is of the same kind as my nature, that can be assimilated by it, I envy, I aspire to, I make my own; beyond that, benevolent nature has armed me with insensibility, coldness, and blindness; it may even be contempt and disgust-but it only has the purpose of throwing me back upon myself, of giving me enough in the center to support me. ${ }^{18}$

For Bishop Berkeley of Ireland, the Platonically optimistic view of knowledge went hand in hand with an equally optimistic view of the basis of human conduct. For Weimar's chief pastor Herder, epistemological relativism was paired with an axiological relativism.

Herder undoubtedly describes something that occurs all too frequently. But does he also describe something that alone is humanly possible, that is always the case by dint of structure? Does he reveal a relativism to which there is absolutely no alternative? These questions carry weight because Herder's position leads to radical consequences that have indeed been taken by radical thinkers.

Joseph de Maistre, a social scientist at the rightist, restorative end of the political spectrum, saw and took the consequences:

There is no human being in the world. In my life, I have seen Frenchmen, Italians, Russians, etc. Thanks to Montesquieu I even know that one can be a Persian. But as far as the human being is concerned, I declare that J have never in my life encountered one; if he exists, then probably without my knowledge. 19

Declarations of this kind are certainly not merely of historical interest. Spurred by the current objective of seeking orientation through independent experience of 
their own, feminists gravitate toward the same conclusion as regards its negative side. The positive side is weighted with other priorities. Negative: There is not a human species. Positive: There are women and men; females and males.

History underscores the parallelism. Feminists rightfully draw attention to the fact that in cultural anthropology, under the heading of Orientalism, the same conceptual dualities and schematic thinking are applied to the difference between Asia and Europe as, in psychology and sociology, to the difference between woman and man.

Anthropology today, especially anthropology of a biological and linguistic orientation, offers a means of escaping the hopelessly oversimplifying dichotomies of European vs. Asian and masculine vs. feminine in the sense of intellectual vs. sensual, rational vs. emotional, legalistic vs. opportunistic/pragmatic, predictable vs. unpredictable, etc. ${ }^{20}$ This escape might be elaborated by reflecting on a contemporary formulation of the conclusion drawn by radical thinkers from Herder's position, a formulation found in the work of a social scientist-the already mentioned Jürgen Habermas-at the other, emancipatory end of the political spectrum, albeit in an early article which probably reflects the view of his teachers more than the own current persuasion:

The human being does not exist any more than the language does. Since people first make themselves into what they are and each does so differently, according to the circumstances, there are certainly societies or cultures about which general statements can be made as they can be made about species of plants or kinds of animals; but not about the human being. 21

I shall now proceed to argue that it is more likely that the contrary applies.

\section{The Current Synthesis (A Hypothesis)}

The following assumption, diametrically opposed to Habermas's statement, may prove a fruitful principle for the human sciences:

It is easier to make general statements (species-specific) about the human being: statements that apply to all human beings, only to human beings and not to other living beings as well, than to make general statements (populationspecific) about one culture (or one society, one "race," one nation, one epoch, one sex) that apply to all members of that one culture (society, "race," nation, epoch, sex), only to them and not to members of other cultures (other societies, other "races," other nations, other epochs, the other sex).

Striking, scientifically authoritative proof of this principle is furnished by the biologist Stephen Jay Gould:

Human equality is a contingent fact of history. The great preponderance of human variation occurs within groups, not in the differences between them. 22 
To what extent does this principle entail a synthesis of the Platonic and romantic models? This question is best answered and elucidated by dividing the three models - the Platonic, the romantic, and the current synthetic model-into several subtheses, regarding (1) the kind of universality, (2) the domain of variability, (3) the relationship of content to form that governs the three models, (4) the conception of the world, (5) the matching conception of the value system, (6) the structure of languages, (7) the determining factor of Weltanschauung, and (8) the possibility of intercultural understanding.

(1) The Kind of Universality. Within current linguistic research, there is a strong group that shares the view with the Platonic model of Antiquity, the Middle Ages, and the Enlightenment that there is something common to all human beings. It even goes beyond traditional grammatica universalis doctrines. According to the latter, universals are essentially found on the level of semantic categories and not on the level of linguistic expression. Universals of expression, such as the distinction between vowels and consonants, were considered irrelevant or even disregarded altogether. Recent, empirical research into universals, on the other hand, characteristically takes the level of expression as its very point of departure. ${ }^{23}$ Its most impressive successes lie in the field of speech sounds and the formation of words and sentences, most effectively and popularly illustrated by the structure of semantic fields, such as words for colors, numbers, kinship, the designation of body parts, personal pronouns, etc.

In contrast to the Platonic model, however, very few universals are now claimed to be ontologically necessary although the existence of some essential universals is undeniable. Remarkably, they are the subject of investigation today in an area where they are least anticipated, in pragmatics. The ability to make a (meaningful) promise is dependent on the ability to believe that the promised is possible and desirable for the addressee.

Empirical linguistics addresses entirely different universals, as in the following illustration from the field of numerals. ${ }^{24}$ Natural languages express higher numbers by utilizing equivalents of basic mathematical operations. It is thereby (hypothetically) assumed that subtraction is not used in any language unless addition is used as well. And in the case of subtraction, it holds that the subtrahend, the number to be subtracted, is smaller than the remainder. In Latin, the word for 18 has the structure of $20-2$ : duodeviginti. In no natural language can a word be found with the structure of $20-12$ for 8 . Such a numerical wordsystem is logically possible and conceivable without inconsistency.

This unprepossessing illustration is remarkable. It proves that not everything that is logically possible is necessarily natural. We can use structural and functional considerations to explain the principles that it substantiates, principles which are related to our cognitive faculties and can be economically explained in 
relation to them. The illustration shows, moreover, that we unconsciously adhere to structural and functional constraints without having the slightest notion that we are doing so. Finally, it refutes the Platonic argument according to which only the essential, the vital, the fundamental is common to all people, and the romantic doctrine, according to which-at most-only unspecific structures of extreme, almost trivial abstractness can be universal but not concrete details for which there is no necessity. 25

(2) The Domain of Variability. According to the Platonic model, variability is restricted to sensory surface structure. According to the romantic model, there are no constraints upon variation, neither horizontal, between the essential and the nonessential, nor vertical, in the structure of a particular culture. The current model, in contrast, acknowledges a profound but still not unrestricted variability. It holds that the romantic thesis with its assumption of homogeneous "peoples" (Kulturnationen) does not do justice to the specialness, complexity, and richness of the variability that is characteristic of mankind. There are, on the one hand, ideas and values that are shared by certain strata of society and certain occupations above and beyond cultural borders. A European farmer may feel a greater affinity with a Chinese farmer than with a city dweller in his own country. Similarly, in natural languages there are laws for the structure of semantic fields that assert themselves independently of linguistic family and type. On the other hand, distinctions can be found within one and the same culture that are no different in manner or extent from the distinctions between cultures. The same conflict regarding different ideas and values that occurs between different people (intersubjectively: intraculturally as well as interculturally) is often found within the single, more reflective person (intrasubjectively).

According to the romantic idea, a culture is a self-contained, homogeneous whole, centralized and hierarchically dominated from its center. But cultures and languages have no fixed boundaries due to their function, their living conditions, and the interests of their members. The transitions between them are flowing. Nor are they as homologous as was taught by Oswald Spengler in the first half and by Michel Foucault in the second half of this century. ${ }^{26}$ Spengler states "that between the differential calculus and the dynastic principle of the state in the age of Louis XIV, between the ancient form of the city state and Euclidean geometry, [...] between contrapuntal instrumental music and the economic credit system, there exists a deep affinity of form."27

Individual cultures, like their physiological vehicle, the human brain, are not homologous and uniform, as the romantic concept of the organism would have it, but rather modular. ${ }^{28}$ Different tasks are carried out with different procedures (modules). These are but loosely related and often not particularly well attuned to each other. Little else is to be expected, given their function and their genesis. The 
idea of homologous/homogeneous development applies neither to cultures nor to biological organisms. To cite Claude Lévy-Strauss's anthropological metaphor transferred by François Jacob to the field of biology, they are the result of tinkering (bricolage), makeshift constructions contingent on environmentspecific needs and arising out of whatever happens to be at hand. ${ }^{29}$

(3) Content and Form. The divergence of the three models of culture stems from their different approaches to the relationship between content and (external) form. The Platonic view holds that form and content are mutually independent; the romantic idea of a whole declares the opposite. Research as it stands today acknowledges and retains the romantic assumption of a natural interdependence of content and form as a step forward, but not the unrestricted extension of this interdependence to the entire context. ${ }^{30}$

Only by distinguishing the interdependence of content and its form of expression from the interdependence of text and context can one understand how content-defined cultural universals are even possible. If content depends on form, and if the formal means used by languages are to a considerable extent universally the same, then universal traits may also be anticipated, on the level of content, in the concrete manner in which the world is experienced and contrived. On the other hand, universals of content are only possible if cultures are not traditional wholes in which each part strictly depends on every other part. Since every culture has its own history and its own geographical area, it would follow, from the romantic idea of the whole, that every sector of a given culture with its dependence on the specific cultural context is special, unique, and down to the finest detail fundamentally different from corresponding sectors in other cultures. But if cultures are nonclassical, nonromantic wholes, in which strict relations of interdependence apply only locally and regionally but not globally, then sectors of different cultures can be compared to each other. It is then possible that, because they have the same form, corresponding fields of objects in different cultures will be subject to the same laws-despite the difference in the overall cultural framework. This is precisely the conclusion suggested by linguistic field research when it observes the same laws at work in the word-fields of different languages.

(4) The Conception of the World. According to the Platonic model of culture "that which holds the world together in its inmost being" (Goethe) does so as a matter of ontological necessity. Only its sensible appearances are a matter of chance. The world as viewed by the romantic model, in contrast, is either structureless, amorphous (Saussure: "ce royaume flottant"31), chaotic (Whorf: "a kaleidoscopic flux"32), or of a structure subject to indefinite change (A. R. Wallace: "On the Tendency of Varieties to Depart Indefinitely from the Original Type"33), or of an inscrutable structure (Quine: "inscrutability of reference"34), or 
of a structure subject to indefinite interpretation (Duhem: "underdeterminacy of physical theories"35).

According to the synthetic model, nature, including that of the human species, is also of an astonishing but by no means unbounded variability. In physics, in biology, and in the human sciences, researchers always come across states that are more stable ("more natural") than others, their stability being something which can be explained by their structure or function. ${ }^{36}$ Moreover, the world seems to be a whole whose parts cannot all be realized at once, but only alternatively or complementarily. The realization of certain possibilities excludes that of others. According to both the classical and romantic ideal of the whole, which holds that every part is dependent upon every other part, the perfection of single parts presupposes the unrestricted presence and display of all the other parts. According to the current, alternative model of wholes, the parts that go to form a whole may be mutually incompatible and may exclude simultaneous realization. 37

(5) The Conception of the Value System. According to the Platonic model, values form a hierarchical, pyramid-shaped, harmonious, universally valid and therefore stable system. According to the romantic model, there are several such pyramids of values, each with a different topmost value, a different focus, a different orientation. The ranking of the values is labile, varying from culture to culture and from epoch to epoch. Something may be valuable in one culture that is worthless or even bad in another. The current synthetic model shares with the romantic model the idea of variable orders of values, but tends to share with the Platonic model the view that the exchangeability of positive and negative signs is a misunderstanding. Involved here is not a classical relativity of values (what is good for one person is bad for the other, or conversely), but rather a polytheism of values, as a battle not between God and the Devil but between different Gods, a conflict of goods, a dispute about what is more and what is less important. ${ }^{38}$ On the other hand, no order of values, not even a compromise among orders of values, is without negative side effects. Unlike the Platonic model, there is no unidirectional development for the current model-neither ontogenetically, from the world of the child to the world of the adult, nor historically, from a traditional to a modern society - that is, in every respect, an evolution toward the good, a progression from something faulty to something perfect.

The values cherished by all humans or only by individual cultures or even only by single individuals do not form a hierarchical but rather a heterarchical system. Heterarchical thinking distinguishes the current model of culture from both the Platonic and the romantic models. ${ }^{39}$ Not infrequently several values, whose optimal realization is not simultaneously possible, may assert themselves with the same tenacity. As to the decision to be made in a concrete conflict of 
values, there is no permanent, intersubjective agreement, and, given a nondogmatic state of mind, there is no intrasubjective conviction without uncertainty.

(6) The Structure of Languages. According to the Platonic model, the surface structure of languages happens to be the way it is-changeable and particular. Inasmuch as people do not, by nature, form the appropriate linguistic designations with respect to things and their ideas, it is the task of philosophers to secure the correctness of names (Kong Fu $\mathrm{Zi}$ : zheng ming ${ }^{40}$; Plato: onomaton orthotes $^{41}$ ) so that (according to Plato) words and sentences render things as they are or so that (according to Confucius) people and their artefacts correspond to the designations that were once advisedly established for them.

According to the romantic model, languages, their expression and meaning, are what they are through historical contingency. Their structure is not accessible to foreigners through the things of the world which they designate, but only by deciphering (cracking ${ }^{42}$ ) the code of which they are constituted, i.e., the subjective attitude that determined the choice of code.

According to the new model, the structure of languages and the possible directions their change may take are determined by phylogenetic and neurological factors and show an astonishing degree of similarity among all people. The universal laws regarding expression in language, which are empirically investigated and "naturally" explained in terms of the languages' structure and function, entail universal laws regarding the meaning level of languages as well, due to the interdependence of form and content.

(7) The Determining Factor of Weltanschauung. According to the Platonic model, the structure of the world determines the structure of the (mental) image of the world-universally and always in the same way. Only the structure of the sensory experience of the world depends, like that of linguistic forms of expression, on happenstance.

According to the romantic model, the structure of language determines the structure of the (sensory and intellectual) Weltanschauung-in each case in different ways. The structure of language depends on the structure of the way a "people" lives, and this in turn on the historical (social) and geographical (climatic) living conditions.

According to the current model, the structure of brain and mind determines both the structure of the (sensory and intellectual) Weltanschauung and that of language-universally, following the same constraints of variation in a diversity of ways. Nature, brain, culture, and language are to a large extent the outcome of co-evolution in the early stages of human history. 43

(8) The Possibility of Intercultural Understanding. According to the Platonic model, understanding between cultures is possible through recourse to things and to the ideas that people naturally acquire of these things. 
According to Herder's romantic model, a culture will appreciate foreign cultural achievements only insofar as they can be assimilated. Adoption is equivalent to integration. Understanding is pursued from the culture's own point of view and never from that of the foreign culture.

For the current model, four insights are decisive:

(a) Phenomena can be defined in various cultures that transcend linguistic constraints and are subject to the same laws. Such universal laws form a bridgehead from which a foreign culture can be accessed.

(b) Every person is able to acquire any language and any culture into which she or he is born. Foreign cultures give us access to possibilities of development which are apparently at our disposal by nature and which only circumstances prevent from appearing in our own culture. Different cultures develop different human skills to varying degrees.

(c) The same problems of understanding, encountered through contact with a foreign culture, confront us in our own culture when we address past epochs or nascent developments. We grow into our own multi-shaped culture by learning in childhood to take different standpoints and pit them against each other.

(d) As everyone knows from acquiring a second language, our passive competence is superior to our active competence. We understand more than we can ourselves say. It is easier for us to imitate a model or to perform according to instruction than to develop something independently and creatively. Therefore, if we are bogged down in our own culture with our own history, it is wise to take a look at foreign traditions. ${ }^{44}$

Swiss Federal Institute of Technology (ETH)

Elmar Holenstein

Zürich

\section{NOTES}

1. Peri hermeneias, 16 a.

2. Cratylos, 390a.

3. Boethius Dacus (around 1270), quoted in: Jan Pinborg, Die Entwicklung der Sprachwissenschaft im Mittelalter (Münster: Aschendorff, 1967), pp. $79 f$.

4. Gottfried Wilhelm Leibniz, Nouveaux essais sur l'entendement humain, (written) 1703/(published) 1765, sec. 3.4.17.

5. Edmund Husserl, Logische Untersuchungen, 1901/1913 (A 317-321/B 334-342).

6. According to Chomsky himself, "universal grammar is taken to be the set of properties, conditions, or whatever that constitute the 'initial state' of the language learner," i.e., a system of highly abstract principles, not, however, specific rules, elements or 
"features common to all languages." See Noam Chomsky, Rules and Representations (New York: Columbia University Press, 1980), p. 69 et passim.

7. Leibniz, Nouveaux essais, sec. 1.2.18; see also sec. 2.18.10.

8. Rig Veda, 1.164.46.

9. Cf. Encyclopédie de l'Islam, Nouvelle édition (Leiden: Brill, 1963), vol. 2, p. 797 (item: al-Farabi).

10. Nicolaus de Cusa, De pace fidei, (written) 1453/(published) 1488, sec. 1.6.

11. Jürgen Habermas, "Die Einheit der Vernunft in der Vielheit ihrer Stimmen," in: Einheit und Vielheit: XIV. Deutscher Kongress für Philosophie, Giessen 1987, ed. by Odo Marquard (Hamburg: Meiner, 1990), pp. 11-35.

12. Cf. Elmar Holenstein, "Vergleichende Kulturphilosophie: Chinesische Bilder, japanische Beispiele, schweizerische Verhältnisse," in: Philosophische Grundlagen der Interkulturalität, ed. by R. A. Mall and D. Lohmar (Amsterdam: Rodopi, 1993), pp. 125f.

13. Arthur Schopenhauer, "Sinologie," in: Werke in zehn Bänden: Zürcher Ausgabe (Zürich: Diogenes, 1977), vol. 5, p. 328.

14. John Locke, An Essay concerning Human Understanding, 1690, sec. 4.5 .4 ("one should desire them to think only of the Things themselves, and lay by those Words, with which they often confound others, and not seldom themselves also"); sec. 4.6 .1 ("the examining and judging of ideas by themselves, their names being quite laid aside, be the best and surest way to clear and distinct knowledge").

15. Husserl, 1901/1913, Introduction (A 7/B 6): "Wir wollen auf die 'Sachen selbst' zurückgehen."

16. George Berkeley, The Principles of Human Knowledge, 1710/1734, sec. 24.

17. Wilhelm von Humboldt, Uber die Verschiedenheit des menschlichen Sprachbaues und ihren Einfluss auf die geistige Entwicklung des Menschengeschlechts (1836), in: Schriften zur Sprachphilosophie (Stuttgart: Cotta, 1963), pp. 433f.

18. J. G. Herder, Auch eine Philosophie der Geschichte zur Bildung der Menschheit (1774) (Frankfurt am Main: Suhrkamp, 1967), pp. 44f.

19. Joseph de Maistre, "Considérations sur la France" (1814), in: Oeuvres complètes (Lyon: Vitte, 1891), vol. 1, p. 74.

20. For a list of 37 dichotomies, see Peter N. Dale, The Myth of Japanese Uniqueness (London: Routledge, 1986), pp. 42-51.

21. Jürgen Habermas, "Philosophische Anthropologie" (1958), in: Kultur und Kritik (Frankfurt am Main: Suhrkamp, 1973), p. 106.

22. Stephen Jay Gould, "Human Equality Is a Contingent Fact of History," in: The Flamingo's Smile (New York: Norton, 1985), pp. 186, 196. For the same view proposed on the basis of linguistic evidence, see Elmar Holenstein, Menschliches Selbstverständnis (Frankfurt am Main: Suhrkamp, 1985), p. 149.

23. See especially the pioneering work of the Prague Linguistic Circle in the 'twenties and 'thirties, and of Joseph H. Greenberg at Stanford in the 'sixties and 'seventies: Roman Jakobson, Selected Writings I: Phonological Studies (The Hague: Mouton, 1971); Universals of Language, ed. by Joseph H. Greenberg (Cambridge, MA: M.I.T. Press, 1963); Universals of Human Language, 4 vols. ed. by Joseph H. Greenberg (Stanford, CA: Stanford University Press, 1978). For a general survey on the research into language universals between 1929 and 1984 and its philosophical implications, see Elmar Holenstein, Sprachliche Universalien (Bochum: Brockmeyer, 1985).

24. Cf. Joseph H. Greenberg, "Generalizations about Numeral Systems," in: Universals of Human Language, ed. by J. H. Greenberg (Stanford, CA: Stanford University Press, 1978), vol. 3, pp. 249-96. 
25. For some examples of this "relationalistic" doctrine, see Holenstein, Sprachliche Universalien, 1985, pp. 55f.

26. Cf. John C. Greene, "Les mots et les choses [de Michel Foucault]," in: Social Science Information 6 (1967), p. 134.

27. Oswald Spengler, Der Untergang des Abendlandes (München: Beck, 1918/1923), vol. 1, p. 8.

28. For a hierarchical schema of the human brain, see Wilhelm Wundt, Grundzïge der physiologischen Psychologie (Leipzig: Engelmann 1880), vol. 1, p. 219.

29. Claude Lévi-Strauss, La pensée sauvage (Paris: Plon 1962) pp. 26-47; François Jacob, "Evolution and Tinkering," in: Science 196 (June 1977), 1161-66.

30. Cf. Elmar Holenstein, Roman Jakobson's Approach to Language: Phenomenological Structuralism (Bloomington, IN: Indiana University Press, 1976), pp. 69-89; "Jakobson's Philosophical Background," in: Language, Poetry and Poetics, ed. by Krystyna Pomorska (Berlin: de Gruyter, 1987), p. 18. According to Jakobson, the assumption that form and substance are not independent of each other distinguishes a structuralist from a formalist.

31. Ferdinand de Saussure, Cours de linguistique générale (Paris: Payot, 1916/1933), p. 155.

32. Benjamin L. Whorf, Language, Thought and Reality (Cambridge, MA: M.I.T. Press, 1956), p. 213.

33. This is the title of the well-known paper presented to the Linnean Society on July 1, 1858, together with Charles Darwin's paper "On the Tendency of Species to Form Varieties," in: Journal of the Linnean Society (Zoology) 3 (1858), 45-62. See also Martin Joos's rebuttal of the Linguistic Circle of Prague which "tried to explain everything from a minimum set of phonological laws taken as essentially valid for all languages alike, flatly contradicting the American (Boas) tradition that languages could differ from each other without limit and in unpredictable ways," in: Readings of Linguistics, ed. by Martin Joos (Chicago: Chicago University Press, 1957), vol. 1, p. 96n.

34. W. V. Quine, Ontological Relativity and Other Essays (New York: Columbia University Press, 1969), pp. 30-41 et passim.

35. Pierre Duhem, La théorie physique, son objet et sa structure (Paris: 1906), ch. 8.

36. Cf. V. F. Weisskopf, "The Role of Symmetry in Nuclear, Atomic and Complex Structures," in: Nobel Symposium 11 (1969), 35-39.

37. Cf. Hans Primas, "Chemistry and Complementarity," in: Chimia 36 (1982), p. 295.

38, Max Weber, "Wissenschaft als Beruf" (1919), in: Gesamtausgabe (Tübingen: Mohr, 1992), vol. 1/17, pp. 99f.

39. Cf. Margret A. Boden, Artificial Intelligence and Natural Man (Hassocks: Harvester, 1977), pp. 125ff.

40. Cf. Robert H. Gassmann, Cheng Ming: Richtigstellung der Bezeichnungen (Bern: Lang), 1988.

41. "On the Correctness of Names" is the subtitle of Plato's dialogue Cratylos.

42. Roman Jakobson and Morris Halle, "Phonology and Phonetics" (1956), in: R. Jakobson, Selected Writings (The Hague: Mouton, 1971), vol. 1, p. 475: "Unlike the decoder [the native hearer], the cryptanalyst comes into possession of a message with no prior knowledge of the underlying code and must break this code through dexterous manipulations of the message." See also Holenstein, Menschliches Selbstverständnis, 1985, p. 133. 
43. Elmar Holenstein, "Koevolutionäre Erkenntnistheorie," in: Transzendentale oder evolutionäre Erkenntnistheorie?, ed. by Wilhelm Lütterfelds (Darmstadt: Wissenschaftliche Buchgesellschaft, 1987), pp. 307-33.

44. This paper pursues and elaborates on earlier work regarding intercultural relations and multicultural settings. Cf. Elmar Holenstein, Menschliches Selbstverständnis (Frankfurt am Main: Suhrkamp, 1985), pp. 104-205; "Europa und die Menschheit" in: Phänomenologie im Widerstreit, ed. by Christoph Jamme and Otto Pöggeler (Frankfurt am Main: Suhrkamp, 1989), pp. 40-54; and, most closely related to this paper, "L'herméneutique interculturelle," in: Revue de théologie et de philosophie, 126 (1994), pp. 19-38. Fertile soil for the most important considerations discussed here was found in the procedures and findings of recent research into language universals. Cf. also Elmar Holenstein, Sprachliche Universalien: Eine Untersuchung zur Natur des menschlichen Geistes (Bochum: Brockmeyer, 1985). I would like to thank Catherine Schelbert for her translation of this article. 